\title{
Determinant of Satisfaction and Repurchase Intention on E- commerce: A Case Study of Housewife in Indonesia
} Bahalwan Apriyansyah, Salasatri Rafaa Dinni, Berto Mulia
Wibawa,

\author{
Departement of Business Management, Institut Teknologi Sepuluh Nopember, \\ Indonesia
}

\begin{abstract}
The development of a digital-based economy creates potential opportunity upon e-commerce platform service provider. Moreover, in pandemic situation shopping online support the large-scale social restriction. There are many well-known e- commerce brands in Indonesia both domestic and international establishment. The competition is in the red ocean which comprising many competitors who have strong leadership strikes penetration of the market. Innovation towards strategy to make consumer kept staying must be very important especially on how to lead them to do repeat order. However, many firms still neglect this factors. Switching behavior from the individual's attitude towards the other e-commerce brands become threat for the certain e-commerce brand's loyal customer. Therefore, this particular research focus on house-wife who fit-matched with the research profile respondent where mostly the house-wife plays significant role on decision and purchase making in a family. This research has purposes to analyze the factors that might influence the satisfaction and repurchase intention in e-commerce platform. In addition to that, analyze the correlation of brand leadership perception towards satisfaction and repurchase intention. Lastly, identify the characteristic of house-wife by looking at repeat order intention upon the brand leader. Conclusive-descriptivemultiple cross sectional research model by using statistical approach of PLS-SEM was conducted in this research. 265 housewives were recruited as respondent by using online survey across Indonesia. Study found that perceived value and popularity are directly related positively and significantly affect satisfaction and repurchase intention. Future research is encouraged to use longitudinal design in providing a holistic understanding of perceived brandleadership
\end{abstract}

Keywords: E-commerce Brand, Customer Satisfaction, Repurchase Intention, Brand Leadership, PLS-SEM

\section{INTRODUCTION}

Information technology has developed rapidly that give an impact to the economy of the world. In Further developing, digital economy become new phenomena which has many strategic roles towards global economy. In line with Huawei and Oxford Economics with the title of Digital Spillover in 2016. The economy of the world has reach out nearly 11.5 trillion dollar or equally with 15.5 percent from world's GDP [1]. The actuality of economy digital-based could be very advantageous for the economy from the transaction up to digital-based investing industry in Indonesia [2]. Evidently, digitalbased economy value is increasing since 2015 and continue keep increasing from US\$ 40 billion in 2019 become US\$ 130 billion in 2025. This make Indonesian the country with the fastest digital-based economy growth in Southeast Asian [3].
According to google report, Temasek and Bain with the title of e-Conomy SEA 2019, there are 4 sectors with highest contribution for the digital-based economy in Indonesia. E-commerce was leading the with value US $\$ 21$ billion in 2019 and estimated become US\$ 82 billion in 2025 . Followed by online travel with value of US\$ 25 in 2025 [4]. The remaining sectors contributed by online press and transportation.

E-commerce become leading sectors for digital-based economy continue to keep growing within decade. Unicorn is the term for the firm's business valuation which exceed US\$ 1 billion. Stated that 3 of Indonesianbased e-commerce 's firms categorized as unicorn firms make Indonesia become top 10 countries with the most unicorn firms in the world [5].

The successfulness of e-commerce in Indonesia has become big attention for the government by issuing the 


\section{Procedia Business and Financial Technology}

Proceedings of the 2nd International Conference on Business and M anagement of T echnology (ICO N BM T 2020) - Part 2

economy package policy XIV regarding the ecommerce[6].

According to previous research conducted by Ernst \& Young, the growth of online business specifically in Indonesia increase about $40 \%$ yearly. Moreover, ecommerce's user widely accessed by either buyer or seller become opportunity for e-commerce platform provider to create the strategies. Henceforth, they compete each other to take over the market by leading the virtual market place, that's the reason why e-commerce war is getting intense day by day in Indonesia. In addition to that, consumer be more aware toward quality and value of the e- commerce provider, also the evaluate the attributes and service provided bythem

[7] as consequences consumers comparing those parameters to their intended product among the ecommerce provider. Switching to the new brand ecommerce provider might happened for certain reason. Nielsen Media [8] postulated Asian consumer have the highest tendency switching the brand about $47 \%$ and followed by Middle east and Sothern America by $45 \%$ and $42 \%$ respectively.

There are two steps to understand the behavior of online consumption. First, identify the factors that influence the customer to buy through online. Second, understand the intention to do repurchase buying which very important for the successfulness of e-commerce platform provider [9].

In line with Zhang, understand the repurchase intention by the customer is the issuing strategies that need to be addressed to leverage the profitability in the long term in online market [10]. Thus, comprising the motivation to do repurchase from the customer via online through ecommerce is the one of the reason this research is conducted.

Previous study focus on how brand leadership or service influence the customer behavior evaluate the product before decision making [11]. Selecting famous brand or service is not the solely

reason which guarantee of quality and value are satisfactory but also represent the real whocustomers are [12]. However not manyresearch had been conducted to evaluate the brand leadership from customer point of view toward e-commerce platform provider in Indonesia. As a result, the main purposes of this research are identify theperception of e-commerce brand leadership upon satisfaction and repurchase intention based on CognitiveAffective Processing System [13] and Expectation Confirmatory Theory [14] in which e-commerce brand provider in Indonesian become the one of research object. According to the SCG advertising and Public Relation, one of Top Digital Strategy Agencies in New York-based, housewife plays significant role in e-commerce Industry [15]. The surveyrevealed that $70 \%$ of housewife spent up to 4 hours daily accessed social media through their personal device smartphone. They implied that social media give significant influence for housewife as decision maker to buy certain product. In addition to that, segmented housewife become opportunity for the ecommerce firms to analyze factors that might impede the housewife shopping online.

Coronavirus Disease 2019 or well-known as SARS-CoV2 has been hitting the entire world economy growth, without exception in Indonesia. Indonesian Ministry of Finance stated that while the economic slowdown seems inevitable [16]. In the other, pandemic accelerate the pace of digitalization to help in reducing the risk of spreading Covid-19 whereas online shopping support the largescale social restriction in certain region with high impacted area of Covid- 19 spread. Shopping online replaced the conventional buying which requires physical transaction until the vaccine found, hence the existence of online shopping at least would have help the economic stabilization.

\section{LITERATURE REVIEW}

\section{E-commerce Brand and Hypothesis Development}

According to Smith et al., 2010 [17] brand can be name that associated with product and services are offered by the firm or the name refer to specific firms itself. Online market, Javalgi postulated that brand were considered as point of recognition when the consumer doubt or worry regarding product or services. It means services or product are provided by e- commerce representing the brand differentiate itself from other competitors [18]. This research e-commerce was considered as brand of the firm that has own service or product differentiate from other e- commerce providers. Therefore, main focus of this research is evaluate the customer perception towards e- commerce and explore the perception upon customer's decision making

\section{Cognitive-Affective Processing System and Perceived Brand Leadership}

Shod et al. 2013 [19] stated that behavior is the function of how the individual cognitive system respond to one subjective experience from the situation that they're facing. While the positive emotion is appearing to certain situation, thus product that being evaluated would be positive accordinglyand vice versa [20].leadership, those are, quality perception, innovation perception. Value perception and popularity perception.

.




\section{Procedia Business and Financial Technology}

Proceedings of the 2nd International Conference on Business and M anagement of T echnology (ICO N BM T 2020) - Part 2

Customer Satisfaction Oliver (1993) [22] stated that customer satisfaction is a response towards customer fulfilments. Further in his research, he added that satisfaction is not limited to the extent of how happy the customers are and that it can be portrayed as a process (Oliver R., Cognitive, Affective and Attribute Bases of the Satisfaction [22] Every company works towards obtaining high rate of customer satisfaction which leads it to become the key principle in marketing [23]. Customer satisfaction plays an important role towards the success of an online store. It is considered as the main incentive of post-purchase phenomenon, such as repurchase intention [24]. Based on that ground, it is important that e- commerce enterprises and online sellers be familiar with the customer requirements and identify the factors that affect customer satisfaction within the ecommerce framework. [24]

\section{Repurchase Intention}

Customer satisfaction will make an impact towards attitude change, which will eventually affect repurchase intention [25]. Repurchase intention refers to the subjective probability in which a buyer will continuously purchase products from a vendor or an online store in the future [26]. In general, one should acknowledge factors that encourage customers to repurchase for the ecommerce to take off [9]. Repurchase intention is one of the determinants of what a good e-commerce is in the eye of the customers [27].

\section{Expectation -Confirmatory Theory}

Expectation-Confirmation Theory (ECT) is utilized to describe cognitive appraisal and its effect towards the affective value in purchasing process [14]. ECT has been widely used in marketing to evaluate customer satisfaction and post-purchase behaviour [28]. ECT is a two-stage conceptual model. The first stage is the prepurchase in which the expectations develop before the purchase. Those expectations include customer's belief towards what they are going to receive (Kim et al., 2009) [29]. The later stage is the post-purchase which involves three other steps; first, interpretation of customer's initial perceptions when they receive the products, then followed the formation of appraisal out of the perception during the pre-purchase and the perception during the early use of the products. [24]

\section{Conceptual Frame work}

The hypothesis of this research was adopted from the study conducted by Chiu \& Hoo (2019) [18]. Other research concluded that service attribute or variety of product (I.e. appraisal and perceived quality, innovation and popularity) make an impact on the customer satisfaction. Among many aspects of brand leadership, perceived qualityis crucial in the world of e- commerce [18]. Most research show that perceived quality directly affects customer satisfaction based on the perceived value [30]. Furthermore, Chiu \& Hoo (2019) [18] conveyed that perceived value is significantly related to customer satisfaction. They found that innovations on brand leadership greatly affects customer satisfaction. In addition, they also pointed out that perceived popularity towards a brand positively affects satisfaction upon purchasing. Based on cognitive-affective processing system, there is a higher possibility of customer's intention to repurchase when the service provider is able to meet their needs [18]. Customer perception towards popular brands plays a role upon customer decisions and affective behaviors [11]. Chiu \& Hoo (2019) [18] explained that brand leadership not only increases customer satisfaction, but also encourages them to repurchase. Therefore, the hypothesis of this research is to examine the effects of four dimensions of brand leadership (i.e. quality, value, innovation and popularity) towards repurchase intention. Based on ECT, customer satisfaction obtained from previous purchases significantly affects the customer intention to repurchase the products in the future. O. Pappas et al. (2014) [31] further clarified that ECT considers satisfaction as the key variable towards customer intention in repurchasing. Henceforth the research model shown as following figure.

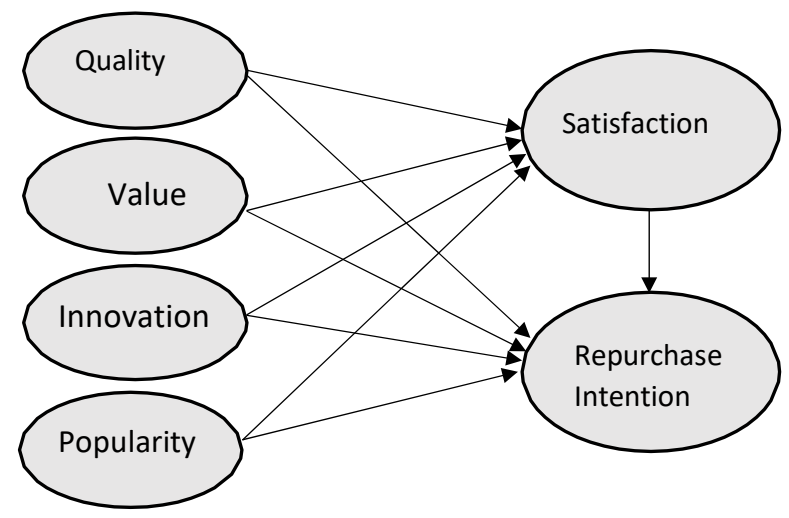

Figure 1 Research Model

H1a Quality perception in e-commerce positively impact towards customer satisfaction

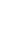

(a)




\section{Procedia Business and Financial Technology}

Proceedings of the 2nd International Conference on Business and M anagement of T echnology (ICO N BM T 2020) - Part 2

H1b Value perception in e-commerce positively impact towards customer satisfaction

H1c Innovation perception in e-commerce positively impact towards customer satisfaction

H1d Popularity perception in e-commerce positively impact towards customer satisfaction

H2a Quality perception in e-commerce positivelyimpact towards repurchase intention

$\mathrm{H} 2 \mathrm{~b}$ Value perception in e-commerce positively impact towards repurchase intention

$\mathrm{H} 2 \mathrm{c}$ Innovation perception in e-commerce positively impact towards repurchase intention

H2d Popularity perception in e-commerce positively impact towards repurchase intention

H3 Satisfaction lead positively torepurchase intention

\section{METHODOLOGY}

This research was conducted using conclusive descriptive research design. Conclusive research is designed to draw conclusion in determining, evaluating and choosing the best alternatives upon problem solving [32]. It is said descriptive because it describes the characteristics of housewives as customers who use ecommerce unicorn in Indonesia. Online surveywas carried out to gather the data. The respondents werehousewives whohave purchased some products using e-commerce; they were asked to fill out online questionnaire. The questionnaire employs Linkert scale as the benchmark in determining the interval of quantitative data within Partial Least Square-Structural Equation Modelling (PLS - SEM) analysis to identify the factors that could affect satisfaction. To determine the samples, the researcher usedthe rule of thumb theory; multiplying the number of variable indicators 5 to 10 times [33]. Hence, about 265 samples were recruited to conduct this research.

This self-administrated questionnaire was distributed through personal contacts and broadcasted on social media (i.e. Facebook, Instagram and Twitter), enabling the respondents to fill it out independently. The questionnaire was assembled into a Google form to reach the respondents residing in different areas.

Assumption test measures the complexity of correlation as well as the complexity of the results and analyses [33].
It is important to identify any outliers, to test normality and linearity for SEM analysis [34].

This research referred to Chiu and Hoo (2019) [18] in designing the model related to the variables of perceived quality, perceived value, perceived innovation, perceived popularity, customer satisfaction and repurchase intention.

\section{RESULTS}

Descriptive Analysis

A total of 265 questionnaires were collected. After eliminating 18 responses that did not pass the screening, 247 questionnaires were used for the data analysis. The

majority of respondents were aged between 19 and 30 years old $(57,1 \%)$. Most respondents are bachelor or diploma graduates $(51,4 \%)$. Most of them have a combined income over Rp 5.000.000. And the last, 68,9 percent of them live in East Java.

Table 1 Descriptive Analysis

\begin{tabular}{|c|c|c|}
\hline Descriptive Analysis & $\mathrm{N}$ & Frequency $(\%)$ \\
\hline \multicolumn{3}{|l|}{ 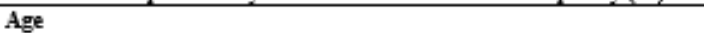 } \\
\hline $19-30$ & 141 & 57,1 \\
\hline $31-40$ & 47 & 19 \\
\hline $41-50$ & 34 & 13,8 \\
\hline $51-60$ & 25 & 10,1 \\
\hline Total & 347 & 100 \\
\hline \multicolumn{3}{|l|}{ Last Education } \\
\hline Elementary scnool & 3 & 1.2 \\
\hline 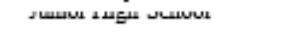 & 17 & 6,9 \\
\hline 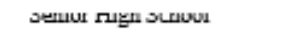 & 86 & 34,8 \\
\hline Bacneior/Lipioma & 127 & 51,4 \\
\hline \multirow[t]{2}{*}{ Postgraduate (S2 or S3) } & 14 & 5,7 \\
\hline & 247 & 100 \\
\hline \multicolumn{3}{|l|}{ Average Combined Income per } \\
\hline $\begin{array}{l}\underbrace{}_{\operatorname{En}} 1.000 .000 \\
\operatorname{En} 1.000 .000-\operatorname{Rn} 2.000 .000\end{array}$ & $\begin{array}{l}30 \\
48\end{array}$ & $\begin{array}{l}14,0 \\
19,4\end{array}$ \\
\hline $\operatorname{Rn}, 2.000 .001-\mathrm{B}, 3.000 .000$ & 44 & 17,8 \\
\hline$B n, 3.000 .001-\operatorname{Bn} 4.000 .000$ & 21 & 8,5 \\
\hline $\mathrm{B}_{2} 4.000 .001-\mathrm{B} p 5.000 .000$ & 32 & 13 \\
\hline$>\operatorname{Bg}, 5.000 .000$ & 66 & 26,7 \\
\hline Total & 241 & 100 \\
\hline \multirow{6}{*}{$\begin{array}{l}\text { Balı } \\
\text { Banten }\end{array}$} & 4 & 1.6 \\
\hline & 9 & 3,6 \\
\hline & 10 & 4 \\
\hline & 15 & 6,1 \\
\hline & 15 & 6,1 \\
\hline & 17 & 6,9 \\
\hline East Java & 170 & 689 \\
\hline West Kalimantan & 1 & 0,4 \\
\hline East Kalimantan & 1 & 0,4 \\
\hline KepulauanRiau & 1 & 0,4 \\
\hline NTT & 1 & 0,4 \\
\hline West Sumatra Barat & 2 & 0,8 \\
\hline South Sumatra & 1 & 0,4 \\
\hline Total & 247 & 100 \\
\hline
\end{tabular}




\section{Procedia Business and Financial Technology}

Proceedings of the 2 nd International Conference on Business and M anagement of T echnology (ICON BM T 2020) - Part 2

Most respondents $(31,6 \%)$ spend $\mathrm{Rp} 1.000 .000$ per month to shop and Rp 100.000-Rp 200.000 per month for spending via e-commerce. Most housewives like Shopee $(76,1 \%)$. They also use Shopee more often and assume that the Shopee app has the best features. Most respondents chose to shop through e-commerce because of the ease of access $(21,6 \%)$ and has a cheap price $(10,5 \%)$. In one month, most housewives shop 1-2 times in e-commerce $(55,1 \%)$. Most housewives shop for their own personal needs rather than household needs, such as fashion $(35,6 \%)$ and beauty $(21 \%)$.

\section{Table 1 Descriptive Analysis (Con't)}

\begin{tabular}{|c|c|c|}
\hline Deseripeive Anahsis & $\underline{\mathrm{n}}$ & Frequency (96) \\
\hline $\begin{array}{l}\text { Average Spending per Month } \\
<\mathrm{B} p, 1.000 .000 \\
\mathrm{Rn} 1.000 .000-\mathrm{Rp} 2.000 .000\end{array}$ & $\begin{array}{l}78 \\
84\end{array}$ & $\begin{array}{r}31,6 \\
34\end{array}$ \\
\hline $\begin{array}{l}\mathrm{R}, 2.000 .001-\mathrm{Rp} 3.000 .000 \\
\mathrm{R}, 3.000 .001-\mathrm{Rp} 4.000 .000\end{array}$ & $\begin{array}{l}38 \\
20\end{array}$ & $\begin{array}{r}15,4 \\
8,1\end{array}$ \\
\hline Be 4.000.001-Rp 5.000.000 & 15 & 6,1 \\
\hline$>\operatorname{Bp}, 5.000 .000$ & 12 & 4,9 \\
\hline Total & 247 & 100 \\
\hline \multicolumn{3}{|c|}{ 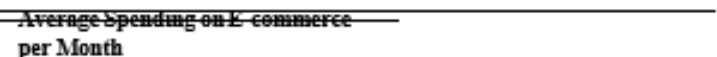 } \\
\hline $\begin{array}{l}<R_{R} 100.000 \\
R p_{1} 100.000-R_{p} 200.000\end{array}$ & $\begin{array}{l}40 \\
83\end{array}$ & $\begin{array}{l}16,2 \\
33,6\end{array}$ \\
\hline Re $200.001-R p 300.000$ & 62 & 25,1 \\
\hline $\mathrm{Bp}, 300.001-\mathrm{Rp} 400.000$ & 25 & 10,1 \\
\hline$>\mathrm{Rp} 400.000$ & 37 & 15 \\
\hline - Poter & 24 & -104 \\
\hline \multicolumn{3}{|l|}{ Mestlitee } \\
\hline Lazada & $\frac{19}{17}$ & 6,9 \\
\hline Bulkslapsk & 10 & 4 \\
\hline $\begin{array}{l}\text { Shopes } \\
\text { tobopesua }\end{array}$ & $\begin{array}{r}188 \\
15\end{array}$ & $\begin{array}{l}76,1 \\
5,2 j\end{array}$ \\
\hline Total & 247 & 100 \\
\hline
\end{tabular}

\begin{tabular}{lrr} 
The Best Feature & & \\
& 19 & 7,7 \\
JDID & 12 & 4,8 \\
Lazada & 11 & 4,4 \\
Buksalanak & 191 & 77,3 \\
Shorges & 14 & 5,7 \\
Tokkepedig & & \\
\hline & 247 & 100 \\
Total & & \\
\hline
\end{tabular}

Reasons to Shop via E-commerce

Cheaper price,

Good quality application

More comfortable

Easy access, more comfortable

Have good innovation

Cheaper price, easy access

Cheaper price, easy access, more

comfortable

Cheaper price, good quality $\quad 16 \quad 6,5$

$64 / 180$

\begin{tabular}{|c|c|c|}
\hline $\begin{array}{l}\text { Cheaper price, have goodinnovation, } \\
\text { easy access, more comfortable }\end{array}$ & 5 & 2 \\
\hline The other & 57 & 23 \\
\hline Total & 247 & 100 \\
\hline $\begin{array}{l}\text { Frequency of purchase via e- } \\
\text { commerce per month } \\
1-2 \text { time(g) } \\
3-4 \text { times }\end{array}$ & $\begin{array}{r}136 \\
69\end{array}$ & $\begin{array}{l}55,1 \\
27,9\end{array}$ \\
\hline $5-6$ times & 17 & 6,9 \\
\hline More than 6 times & 25 & 10,1 \\
\hline Total & 247 & 100 \\
\hline
\end{tabular}

Types of products that are often

\begin{tabular}{lcc} 
purchased via e-commerce & 9 & 3,6 \\
Electronic & 88 & 35,6 \\
Fashion & 22 & 8,9 \\
Mom and kid & 52 & 21 \\
Beauty (skincare dan make up) & 5 & 2 \\
Hobby needs & 4 & 1,6 \\
Health & 12 & 4,9 \\
Food and drink & 49 & 19,8 \\
Home appliances and supplies & 6 & 2,4 \\
The other & $\underline{247}$ & $\underline{100}$ \\
\hline Total &
\end{tabular}

\begin{tabular}{lrr} 
JDID & 15 & 6,1 \\
Lazada & 12 & 4,9 \\
Buksalapak & 10 & 4 \\
Shopes & 196 & 79,3 \\
Tokopedia & 14 & 5,7 \\
\hline Total & 247 & 100 \\
\hline
\end{tabular}




\section{Procedia Business and Financial Technology}

Proceedings of the 2nd International Conference on Business and M anagement of T echnology (ICO N BM T 2020) - Part 2

\section{Assumption Test}

The assumption test aims to examine and select data that can be further processed in statistical tests [33]. In esting data against assumptions, researchers used four tests that

Table 2 Assumption Test

\begin{tabular}{|c|c|c|c|}
\hline Test & Criteria & \multicolumn{2}{|c|}{ Result Test } \\
\hline Outlier & $z-5 c o r e \pm 4$ & $\begin{array}{c}\text { Minimum }-3.95 \\
\text { and masksmome } \\
+1,37\end{array}$ & Qualified \\
\hline Normality & $\begin{array}{l}\text { Q-QPIot } \\
\text { indicates that } \\
\text { thedistribation } \\
\text { of data on each } \\
\text { variable isatill } \\
\text { around the } \\
\text { normal line }\end{array}$ & $\begin{array}{l}\text { Normally } \\
\text { distributed }\end{array}$ & Quritited \\
\hline Linearity & $\begin{array}{l}\text { Distribution of } \\
\text { points on scatter } \\
\text { plots that donot } \\
\text { form certain } \\
\text { pattems }\end{array}$ & $\begin{array}{l}\text { Scatter plots do } \\
\text { not form certain } \\
\text { patterns }\end{array}$ & Qualified \\
\hline Multicollinearity & $\mathrm{VIF}<10$ & $\begin{array}{l}\text { VIF values for } \\
\text { all variables }\end{array}$ & Qualified \\
\hline & & $\leq 10$ & \\
\hline Homoscedasticity & $\begin{array}{l}\text { Distribution of } \\
\text { points gnycatter } \\
\text { plots that do not } \\
\text { form certain }\end{array}$ & $\begin{array}{l}\text { scatter plots do } \\
\text { not form certain } \\
\text { patterns }\end{array}$ & Qualified \\
\hline
\end{tabular}

began with the outlier's test, normality test, linearity test, multicollinearity test and homoscedasticity test.

Partial Least Squares Structural Equation Modeling (PLS-SEM)

Partial Least Squares Structural Equation Modeling (PLS-SEM) was employed by SmartPLS 3.0 to validate the measures and test the hypothesized research model. Evaluation is carried out on outer model and inner model. Outer model is used to examine the relationship between indicators of latent variables.

Table 3 Internal Consistency Test

\begin{tabular}{lccc}
\hline \multicolumn{1}{c}{ Variabel } & & Cronbach'sa & Composice Reliabiliny \\
\cline { 1 - 1 } Perceived Quality & & 0,810 & \\
Perceived Value & 0,861 & 0,887 \\
Perceived Innovativeness & & 0,793 & 0,915 \\
Perceived Popularity & 0,772 & 0,878 \\
& & 0,868 \\
Satiafaction & 0,834 & 0,901 \\
Repurchase Intention & 0,870 & 0,920 \\
\hline
\end{tabular}

All latent variables pass the reliability test because each Cronbach's alpha value is more than and equal to 0.7 [32]. Thus, each latent variable is reliable. In addition, the results of composite reliability on all latent variables also pass the specified minimum requirements, i.e. more than and equal to 0.7 . So, it can be concluded that the data has good internal consistency reliability and above the standard. So that it can be used further in research

Table 4 Convergent Validity Test

\begin{tabular}{|c|c|c|c|}
\hline $\begin{array}{l}\text { Latent Variable } \\
\text { Cut-off Vatude }\end{array}$ & $\begin{array}{l}\text { AVE } \\
\leq 0,5\end{array}$ & Indicator Variable & $\begin{array}{c}\text { Outer Loudings } \\
\leq 0,7\end{array}$ \\
\hline Penceived Quality & 0,724 & $\begin{array}{l}\text { OUL.1 } \\
\text { guL.2 } \\
\text { out.3 }\end{array}$ & $\begin{array}{l}0,825 \\
0,825 \\
0,891\end{array}$ \\
\hline \multirow[t]{3}{*}{ Perceived Value } & 0,783 & NIL. & 0,882 \\
\hline & & $\mathrm{NL}-2$ & 0,905 \\
\hline & & $\mathrm{NL}_{3} 3$ & 0,867 \\
\hline Powned & ing & 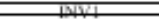 & 2 \\
\hline \multirow[t]{2}{*}{ lmovativeness } & & INV2 & 0,868 \\
\hline & & INV3 & 0,830 \\
\hline \multirow[t]{3}{*}{ Penseived Popularity } & 0,687 & POP1 & 0.825 \\
\hline & & POP2 2 & 0.855 \\
\hline & & POP3 3 & 0.805 \\
\hline \multirow[t]{3}{*}{ Saraslaction } & 0,751 & KFPI & 0,889 \\
\hline & & KFP2 & 0.864 \\
\hline & & KEP3 & 0,846 \\
\hline \multirow[t]{2}{*}{ Repurchase Insention } & 0,794 & NPUI & 0,859 \\
\hline & & NPU2 2 & 0,907 \\
\hline
\end{tabular}

If the value of the outer loadings of each indicator has a value $\leq 0.7$, then the indicator passes the criteria. If not, then the indicator is excluded from the model. In addition, the value of AVE of latent variables must be $\leq 0.5$ in order to pass the convergent validity test. Based on Table, all AVE values of latent variables are more than and equal to 0.5 . The outer loading value of each indicator is also more than and equal to 0.7 . This means that the model that has been prepared is a good model and can be used at a later stage.

Table 5 Discriminant Validity

\begin{tabular}{|c|c|c|c|c|c|c|}
\hline & QUL & NIL & INV & POP & KEP & NPU \\
\hline \multicolumn{7}{|l|}{ QUL } \\
\hline NIL & 0,611 & & & & & \\
\hline INV & 0,727 & 0,600 & & & & \\
\hline POP & 0,657 & 0,732 & 0,631 & & & \\
\hline KEP & 0,656 & 0,790 & 0,626 & 0,908 & & \\
\hline NPU & 0,562 & 0,709 & 0,523 & 0,796 & & \\
\hline
\end{tabular}

If the HTMT value is $\leq 0.9$, then the construct passes the discriminant test. It can be seen that almost all latent variables passed the discriminant test because they have a value of $\leq 0.9$. But HTMT test for perceived popularity with satisfaction is 0,908 . It indicates that the variable has a low discriminant validity value [35]. This shows that between one latent variable with another latent variable 


\section{Procedia Business and Financial Technology}

Proceedings of the 2nd International Conference on Business and M anagement of T echnology (ICO N BM T 2020) - Part 2

in this study is empirically different. variables pass the discriminant test, then reflect that each latent variable is able to capture phenomena that cannot be represented by other latent variables in the model

Table 6 Effect Size Test

\begin{tabular}{|c|c|c|}
\hline Model & Satisfaction & 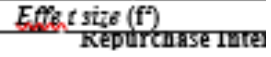 \\
\hline Perceived Quality & 0,021 & 0,008 \\
\hline $\begin{array}{l}\text { Perceived Value } \\
\text { Perceived Innovativeness }\end{array}$ & $\begin{array}{l}0,143 \\
0,011\end{array}$ & $\begin{array}{l}0,114 \\
0,001\end{array}$ \\
\hline Perceived Popularity & 0,307 & 0,201 \\
\hline
\end{tabular}

Based on the value of $\mathrm{f}^{2}$ above, it can be concluded that the goodness of the model or the model that has the most powerful influence is the variable perceived popularity on satisfaction, which is equal to 0,307 . The goodness of the next model is shown by the perceived popularity to repurchase intentions with an effect size value of 0,201 .

\section{Table 7 Result of Path Analysis}

\begin{tabular}{|c|c|c|c|c|}
\hline & Huber & $\begin{array}{l}\text { s Paths } \\
\text { Path }\end{array}$ & $\begin{array}{c}T- \\
\text { Statistics }\end{array}$ & $\begin{array}{c}P \text { - } \\
\text { Values }\end{array}$ \\
\hline HIa & QUL $\$$ KEP & ObBELCLeta & 1,890 & 0,028 \\
\hline $\begin{array}{l}H] b \\
H I C\end{array}$ & $\begin{array}{l}\text { NII } \\
\mathrm{INV} \\
\mathrm{KBP}\end{array}$ & $\begin{array}{l}0,303 \\
0,082\end{array}$ & $\begin{array}{l}4,500 \\
1,377\end{array}$ & $\begin{array}{l}0,000 \\
0,169\end{array}$ \\
\hline$H \perp d$ & PUP \& KEP & 0,448 & 3,923 & 0,000 \\
\hline $\begin{array}{l}H 2 a \\
H 2 b \\
H 2 c\end{array}$ & $\begin{array}{l}\text { QUL } 8 \mathrm{NPU} \\
\text { NII } 8 \mathrm{NPU}\end{array}$ & $\begin{array}{l}0,049 \\
0,226\end{array}$ & $\begin{array}{l}0,771 \\
2,761\end{array}$ & $\begin{array}{l}0,441 \\
0,006\end{array}$ \\
\hline$H 2 \mathrm{C}$ & INV $8 \mathrm{NPU}$ & 0,007 & 0,098 & 0,922 \\
\hline$H 2 d$ & $\mathrm{POP} \approx \mathrm{NPU}$ & 0,288 & 4,195 & 0,000 \\
\hline$H 3$ & $\mathrm{KEP} / \mathrm{NPU}$ & 0,283 & 3,105 & 0,002 \\
\hline
\end{tabular}

coefficient POP $\square$ NPU $=0,288$; $\mathrm{t}=4,195$; $\mathrm{p}$-value $=0,000$ ), supporting $\mathrm{H} 2 \mathrm{~b}$ and $\mathrm{H} 2 \mathrm{~d}$. A significant relationship also occurs in satisfaction on repurchase intention (path coefficient KEP $\square$ NPU $=0,283$; $\mathrm{t}=3,105$; $\mathrm{p}$ - value $=0,002$. However, the paths from quality and innovativeness to satisfaction and repurchase intention were not statisticallysignificant.

\section{MANAGERIAL IMPLICATION}

This research shows e-commerce service providers and marketers focus their efforts on implementing general strategies to meet the factors of brand leadership (i.e. quality, value, innovation, popularity). In general, service providers can improve the quality of application services by fulfilling providing innovation and the quality of information provided in order to create positive cognitive and affective assessments. They also need to implement new ways to attract consumers such as offering ongoing incentives with the product being purchased. At the same time, e-commerce companies need to utilize the expectations of online consumers to match the actual products they offer to increase satisfaction, which in turn influences repurchase intentions. This research has found that value perception and innovation are important factors that influence housewife satisfaction. Therefore, it is important to build a trust platform with the aim of eliminating uncertainty and perceived risk and creating innovation in accordance with the characteristics of housewives in Indonesia. In addition, to attract consumers who do not understand technology, word of mouth is a good marketing tool whose effect is followed by high quality service. Service providerscan adopt content using influencers known as housewives who provide evaluations of products purchased or even picture as proof of the actual service conditions. This content can be associated with new normal conditions, for example housewives can still shop for household needs easily at home without worrying about the possibility of being exposed to COVID-19. At the same time, this guarantees the quality of service which in turn can influence the spending decisions of housewives. Therefore, when the service provider ensures other aspects of brand leadership, word of mouth happens to popularize the brand. This can encourage consumers to switch from offline to online stores and think of it as a leading brand. To increase perceived value, service providers can provide virtual reality assistant systems for consumers to have a better shopping experience. At the same time, they will feel the sophisticated innovations provided by ecommerce. Applying this innovative technology can attract the attention of younger consumers and influence their decision-making processes. It's important for marketers and service providers to be unique in each dimension of their brand and service. Put simply, the findings show that leading brands need to be proactive in developing ways to meet the dimensions of brand leadership and develop unique concepts to attract more housewives.

\section{CONCLUSION}

\section{Research Conclusion}

The customers are dominated by housewives at 19-30 years old, bachelor or diploma as the last level of education, live in East Java, and with a combined average 


\section{Procedia Business and Financial Technology}

Proceedings of the 2nd International Conference on Business and M anagement of T echnology (ICO N BM T 2020) - Part 2

income per month above Rp. 5,000,000. The characteristics of the usage or consumption behavior of the majority of customers make purchases through ecommerce because of the ease of access and most of them consider the products sold to have low prices. Second, most of them claim that the types of products that are often bought are fashion products and most are beauty products. The majority of housewives tend to make purchases through e-commerce with an average frequency of 1 to 2 times within one month.

Based on PLS-SEM analysis, it was concluded that perceived value and popularity are directly related positively and significantly affect satisfaction and repurchase intention. While the perceived quality and innovation does not significantly influence satisfaction and repurchase intention. In addition, this study also found that satisfaction significantly affected the intention to repurchase. This is in line with the ECT theory which states that the level of consumer satisfaction is able to influence them to shape repurchase intentions.

\section{Limitation and Further Research}

Although this study yielded insightful findings, it is not without limitations. First, only respondents in 13 provinces can be reached. Based on the suggestions from respondents, the questions on the questionnaire in this study were quite difficult to understand. So it is feared the data obtained from respondents are inaccurate. There was a huge difference in the number of respondents when they answered questions about e-commerce preferences. So this research does not adequately represent the five ecommerce brands chosen as leaders. Future research is encouraged to use longitudinal design inproviding a holistic understanding of perceived brand leadership. This makes it possible to obtain evidence that the dimensions of brand leadership have a consistent and long-lasting relationship with customer satisfaction and repurchase intentions. Further research can also use quota sampling techniques to find the age distribution, residence, and e-commerce preferences of respondents to be more balanced so that the results obtained are also more general. Having proven that satisfaction has a positive effect on repurchase intentions, further research can discuss customer loyalty to measure long-term relationships based on perceived brand leadership. Further research can also be related to the possibility of customers to do brand switching

\section{REFERENCES}

$67 / 180$

[1] Sugiarto, E. C. (2019, Januari 29). Ekonomi Digital: The New Face of Indonesia's Economy. Accessed on

https://www.setneg.go.id/baca/index/ekonomi_digi tal_the_new_face_of_indonesias_economy

[2] Badan Koordinasi Penanaman Modal. (2019). Bagaimana Potensi Ekonomi Digital di Indonesia? Artikel Investasi. Accessed on https://www.investindonesia.go.id/id/artikelinvestasi/detail/bagaimana-potensi-ekonomidigital-di-indonesia

[3] Katadata. (2019, Oktober 10). Sri Mulyani: Ekonomi Digital RI Tercepat di Asia, Bernilai RP 1.820 T. (A. Agatha Olivia Victoria, Penyunt.)

[4] Hurun Report. (2019, Oktober 21). Hurun Global Unicorn List 2019. (P. Pan, Editor) accessed on https://www.hurun.net/EN/Article/Details?num=A 38B8285034B

[5] databoks.katadata.co.id. (2019, Oktober 4). Inilah Potensi Ekonomi Digital Indonesia 2015-2025. (H. Widowati, Penyunt.) Ekonomi Digital Indonesia.

[6 Rozama, N. A., Siswayu, G., Kusumatrisna, A. L., Untari, R., Ilmiyah, Z., \& Maharani, K. (2019). Statistik E-Commerce 2019. Jakarta: Badan Pusat Statistik.

[7] Mallapragada, G., Chandukala, S. R., \& Liu, Q. (2016). Exploring the effects of 'what'(product) and 'where'(website) characteristics on online shopping behavio. Journal of Marketing, 8(2), 21-38.

[8] Research, N. M. (2019). Battle of The Brands: Consumer Disloyalty is Sweeping The Globe. Accessed on https://www.nielsen.com/us/en/insights/article/201 9/battle-of-the- brands-consumer-disloyalty-issweeping-the-globe/

[9] Zhang, Y., Fang, Y., Wei, K., Ramsey, E., Mccole, P., \& Chen,H. (2011). Repurchase intention in B2C e-commerce - a relationship quality perspective. information \& Management, 48, 192-200.

[10] Li, H. B., Shen, J., \& Hou, F. (2016). Repurchase Intention in Chinese E-marketplace: Roles of Interactivity, Trust and Perceived Effectiveness of 


\section{Procedia Business and Financial Technology}

Proceedings of the 2nd International Conference on Business and M anagement of T echnology (ICO N BM T 2020) - Part 2

E-commerce Institutional Mechanisms. Industrial Management \& Data Systems, 116(8), 1759-1778.

[11] Chang, Y., Ko, Y. J., \& Leite, W. L. (2016). The effect of perceived brand leadership on luxury service WOM. Journal of Services Marketing, 30(6), 659-671.

[12] Chang, Y., \& Ko, Y. J. (2014). The brand leadership: scale development and validation. Journal of Brand Management volume, 21(1), 6380.

[13] Mischel, W., \& Shoda, Y. (1995). A cognitiveaffective system theory of personality: reconceptualizing situations, dispositions, dynamics, and invariance in personality structure. Psychological Review, 102(2), 246-268.

[14] Oliver, R. L. (1980). A cognitive model of the antecedents and consequences of satisfaction decisions. Journal of Marketing Research, 17, 460469.

[15] Fauziyah, A. (2017, Agustus 22). Pengusaha ECommerce, Jangan Remehkan Potensi Ibu Rumah Tangga. Daccessed on digination.id: https://www.digination.id/read/0164/pengusaha-ecommerce-jangan-remehkan-potensi-ibu-rumahtangga

[16 Paine, J. (2020, April 21). In challenging times, digital economy and e-commerce can chart a path toward recovery. Retrieved from The

Jakarta Post:

https://www.thejakartapost.com/academia/2020/04/ 21/in- challenging-times-digital-economy-and-ecommerce-can-chart-a- path-toward-recovery.html

[17] Smith, K. T., Smith, M., \& Wang, K. (2010). Does brand management of corporate reputation translate into higher market value? Journal of Strategic Marketing, 18(3), 201-221.

[18] Chiu, W., \& Hoo, H. (2019). The effect of perceived brand leadership on consumers' satisfaction and repurchase intention on e- commerce websites [diterbitkan secara online sebelum dicetak 25 April 2019]. Asia Pacific Journal of Marketing and Logistic.

[19] Shod, Y., Wilson, N. L., Chen, J., Gilmore, A. K., \& Smith, R.E. (2013). CognitiveAffective Processing System Analysis of Intra- Individual Dynamics in Collaborative Therapeutic
Assessment:Translating Basic Theory and Research Into Clinical Applications. Journal of Personality, 81(6), 554-568.

[20] Pascual, O., Pelegrín-Borondo, J., \& Reinares-Lara. (2016). Cognitive-affective model of acceptance of model phone advertising. E\&M Economics and Management, 19(4), 134-148.

[21] Kim, J., \& Lennon, S. J. (2013). Effects of reputation and website quality on online consumers' emotion, perceived risk and purchase intention: based on the stimulus-organism-response model. Journal of Research in Interactive Marketing, 7(1), 33-56.

[22] Oliver, R. (1993). Cognitive, affective, and attribute bases of the satisfaction response. Journal of consumer research, 20(3), 418- 430.

[23] Kim, D. J. (2012). An investigation of the effect of online consumer trust on expectation, satisfaction, and post-expectation. Information Systems and EBusiness Management, 10(2),219-240.

[24] Fang, Y.-H., Chiu, C.-M., \& Wang, E. T. (2011).Understanding customers' satisfaction and repurchase intentions. Internet Research, 21(4), 479-503.

[25] Oliver, R., \& Bearden, W. (1985). Disconfirmation processes and consumer evaluations in product usage. Journal of Business Research, 13(3), 46-235.

[26] Chiu, C.-M., Chang, C.-C., Cheng, H.-L., \& Fang, Y.-H. (2009).Determinants of customer repurchase intention in online. Online Information Review, 33(4), 761-784.

[27] Novinda, G., \& Sutopo. (2017). Analisis Pengaruh Kualitas Pelayanan dan Kualitas Website terhadap Kepuasan, Kepercayaan dan Niat Pembelian Kembali (Studi pada toko online Blibli. com) (Doctoral dissertation, Fakultas Ekonomika dan Bisnis).

[28] Oh, H. (2000). Diners' Perceptions of Quality, Value, and Satisfaction: A Practical Viewpoint. Cornell Hospitality Quarterly, 41(3), 58-66.

[29] Kim, D. J., Ferrin, D. L., \& Rao, H. R. (2009). Trust and satisfaction, two stepping stones for successful e-commerce relationships: a longitudinal exploration. Information Systems Research, 20(2), 237-257. 


\section{Procedia Business and Financial Technology}

Proceedings of the 2nd International Conference on Business and M anagement of T echnology (ICO N BM T 2020) - Part 2

[30] Choi, E. J., \& Kim, S.-H. (2013). International JournThe Study of the Impact of Perceived Quality and Value of Social Enterprises on Customer Satisfaction and Re-Purchase Intentional of Smart Home. International Journal of Smart Home, 7(1), 239-252.

[31] Pappas, I. O., Pateli, A. G., Giannakos, M. N., \& Chrissikopoulos, V. (2014). Moderating effects of online shopping experience on customer satisfaction and repurchase intentions. International Journal of Retail \& Distribution Management, 42(3), 187-204.

[32] Malhotra, N. K., Birks, D. K., \& Wills, P. (2010). Marketing Research: An Applied Orientation (6th ed.). England: Pearson Education Limited.
[33] Hair, J., Black, W., Babin, B., \& Anderson, R. (2010).Multivariate Data Analysis. New York: Pearson.

[34] Hair, J. F., Ringle, C. M., \& Sarstedt, M. (2013). Partial least squares structural equation modeling: Rigorous applications,better results and higher acceptance. Long range planning, 46(1-2),1-12.

[35] Voorhees, C. M., Brady, M. K., Calantone, R., \& Ramirez, E. (2016). Discriminant validity testing in marketing: an analysis, causes for concern, and proposed remedies. Journal of the Academy of Marketing Science, 44(1), 119-134. 